\title{
Stereotyped Upper Limb Movement in MECP2 Duplication Syndrome
}

Tomohiro Wakabayashi, MD, Shinobu Fukumura, MD, PhD, Satoru Takahashi, MD, PhD, Kenji Kurosawa, MD, PhD, Shuichi Miyamoto, MD, PhD, Kosuke Tsuchida, MD, Shinsuke Kato, MD, Takeshi Tsugawa, MD, PhD, Yoshiyuki Sakai, MD, PhD, and Yukihiko Kawasaki, MD, PhD

Neurology ${ }^{\circledR}$ 2021;97:92-94. doi:10.1212/WNL.0000000000012130

Figure 1 Writhing of Arms and Hands in MECP2 Duplication Syndrome

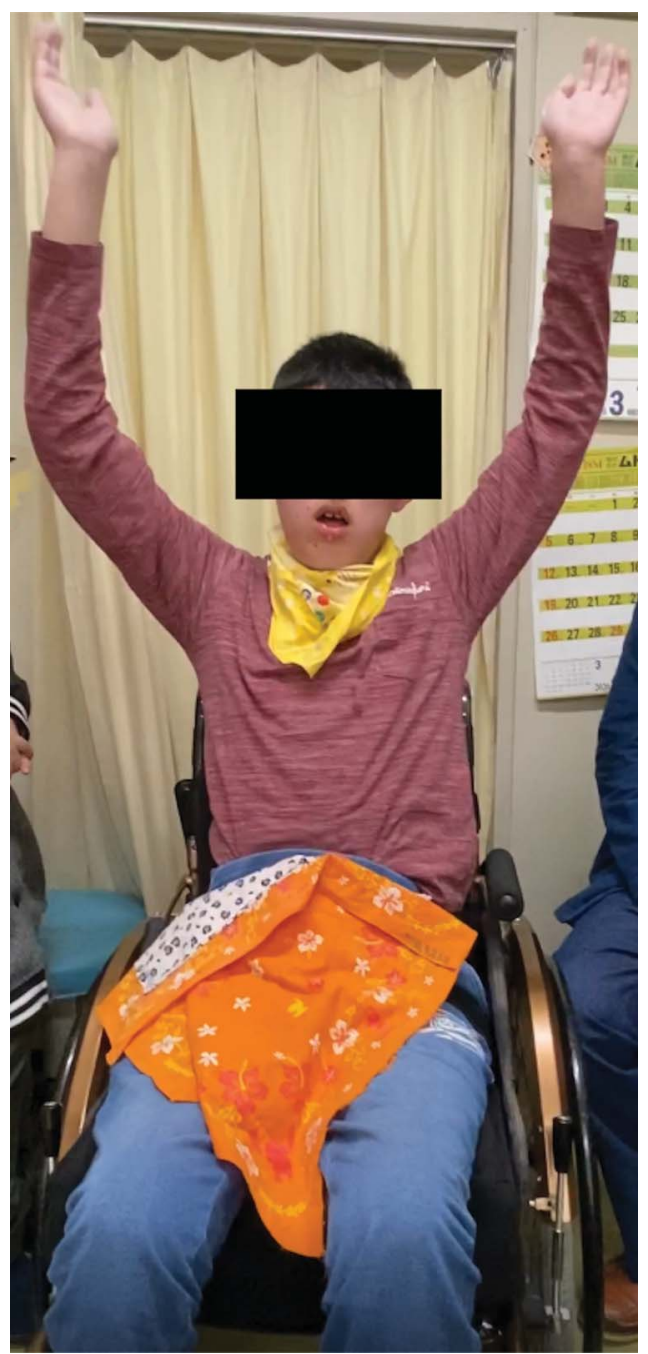

A 23-year-old man had epilepsy, mental retardation, and a stereotyped movement (figure 1 and video1), which was exacerbated by emotion. No abnormality was detected in the EEG during this movement. Array comparative genomic hybridization showed a Xq28 duplication: arr [GRCh37]Xq28(153032004_153406233)x2 (figure 2).

\section{Correspondence}

Dr. Fukumura

fukumura@sapmed.ac.jp

\section{MORE ONLINE}

$\checkmark$ Video

From the Department of Pediatrics (T.W., S.F., K.T., S.K., T.T., Y.K.), Sapporo Medical University School of Medicine; Department of Pediatrics (S.T.), Asahikawa Medical University, Hokkaido; Division of Medical Genetics (K.K.), Kanagawa Children's Medical Center; and Departments of Gastroenterology (S.M.) and Pediatrics (T.W., Y.S.), Hakodate Municipal Hospital, Japan.

Go to Neurology.org/N for full disclosures. Funding information and disclosures deemed relevant by the authors, if any, are provided at the end of the article. 


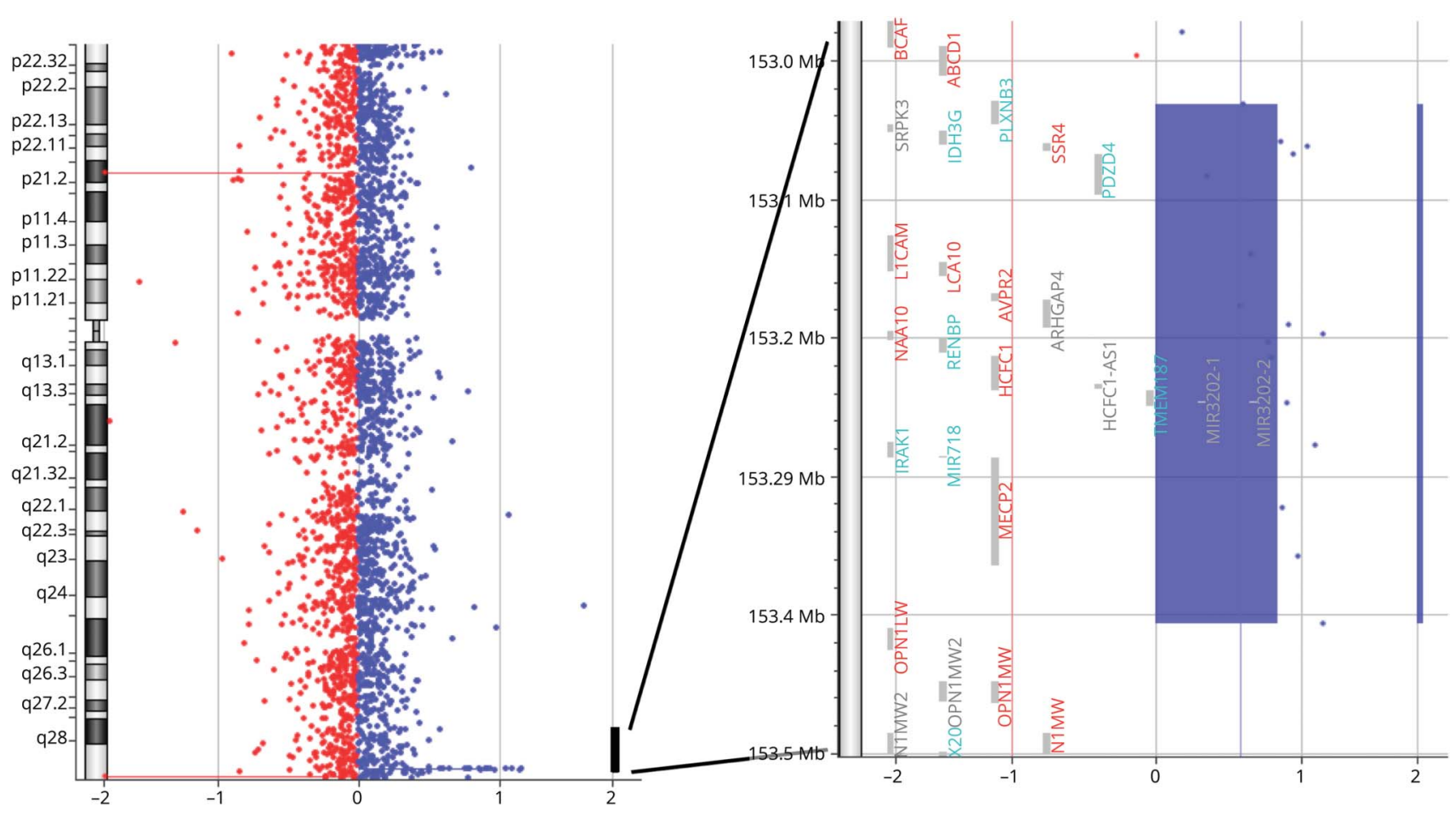

MECP2, IRAK1, and L1CAM were included in the duplication with a size of approximately $0.4 \mathrm{Mb}$. Genomic positions are based on data from the human genome assembly GRCH37/hg19.

The methyl-CpG-binding protein 2 gene (MECP2) duplication syndrome is a rare genetic disease whose causative gene is the same as that for Rett syndrome. The characteristic symptom of both diseases is stereotyped movement. The movement in MECP2 duplication syndrome is writhing arms and hands, ${ }^{1}$ unlike Rett syndrome. ${ }^{2}$

\section{Study Funding}

No targeted funding reported.

\section{Disclosure}

The authors declare that there is no conflict of interest regarding the publication of this article. Go to Neurology.org/N for full disclosures.

\section{Appendix Authors}

\begin{tabular}{lll}
\hline Name & Location & Contribution \\
\hline $\begin{array}{l}\text { Tomohiro } \\
\text { Wakabayashi, }\end{array}$ & Sapporo Medical University & Sesigned and \\
MD & Hakodate Municipal & $\begin{array}{l}\text { conceptualized study, major } \\
\text { role in the acquisition of } \\
\text { Hospital, Hokkaido, Japan } \\
\end{array}$ \\
& $\begin{array}{l}\text { data, analyzed the data, } \\
\text { drafted the manuscript for } \\
\text { intellectual content }\end{array}$ \\
& \\
\hline
\end{tabular}

Appendix (continued)

\begin{tabular}{lll}
\hline Name & Location & Contribution \\
\hline $\begin{array}{l}\text { Shinobu } \\
\text { Fukumura, }\end{array}$ & $\begin{array}{l}\text { Sapporo Medical University } \\
\text { MD, PhD }\end{array}$ & $\begin{array}{l}\text { Designed and } \\
\text { conceptualized study, major }\end{array}$ \\
& Hokkaido, Japan & $\begin{array}{l}\text { role in the acquisition of data, } \\
\text { revised the manuscript for } \\
\text { intellectual content }\end{array}$
\end{tabular}

\begin{tabular}{lll}
\hline $\begin{array}{l}\text { Satoru } \\
\text { Takahashi, } \\
\text { MD, PhD }\end{array}$ & $\begin{array}{l}\text { Asahikawa Medical } \\
\text { University, School of } \\
\text { Medicine, Hokkaido, Japan }\end{array}$ & $\begin{array}{l}\text { Major role in the acquisition } \\
\text { of data }\end{array}$ \\
\hline $\begin{array}{l}\text { Kenji } \\
\text { Kurosawa, } \\
\text { MD, PhD }\end{array}$ & $\begin{array}{l}\text { Division of Medical Genetics, } \\
\text { Kanagawa Children's } \\
\text { Medical, Center, Japan }\end{array}$ & $\begin{array}{l}\text { Major role in the acquisition } \\
\text { of data }\end{array}$ \\
\hline $\begin{array}{l}\text { Shuichi } \\
\text { Miyamoto, } \\
\text { MD, PhD }\end{array}$ & $\begin{array}{l}\text { Hakodate Municipal } \\
\text { Hospital, Hokkaido, Japan }\end{array}$ & $\begin{array}{l}\text { Interpreted the data, revised } \\
\text { the manuscript for } \\
\text { intellectual content }\end{array}$ \\
$\begin{array}{l}\text { Kosuke } \\
\text { Tsuchida, MD }\end{array}$ & $\begin{array}{l}\text { Sapporo Medical University } \\
\text { School of Medicine, }\end{array}$ & $\begin{array}{l}\text { Interpreted the data, revised } \\
\text { the manuscript for } \\
\text { intellectual content }\end{array}$ \\
\hline $\begin{array}{l}\text { Hokkaido, Japan } \\
\text { Kato, MD }\end{array}$ & $\begin{array}{l}\text { Sapporo Medical University } \\
\text { School of Medicine, }\end{array}$ & $\begin{array}{l}\text { Interpreted the data, revised } \\
\text { the manuscript for } \\
\text { intellectual content }\end{array}$ \\
\hline $\begin{array}{l}\text { Hokkaido, Japan } \\
\text { Tsugawa, MD, } \\
\text { PhD }\end{array}$ & $\begin{array}{l}\text { Sapporo Medical University } \\
\text { School of Medicine, }\end{array}$ & $\begin{array}{l}\text { Interpreted the data, revised } \\
\text { the manuscript for } \\
\text { intellectual content }\end{array}$ \\
\hline
\end{tabular}


Appendix (continued)

\begin{tabular}{lll}
\hline Name & Location & Contribution \\
\hline $\begin{array}{l}\text { Yoshiyuki } \\
\text { Sakai, MD, } \\
\text { PhD }\end{array}$ & $\begin{array}{l}\text { Sapporo Medical University } \\
\text { School of Medicine, } \\
\text { Hokkaido, Japan }\end{array}$ & $\begin{array}{l}\text { Interpreted the data, revised } \\
\text { the manuscript for } \\
\text { intellectual content }\end{array}$ \\
\hline $\begin{array}{l}\text { Yukihiko } \\
\text { Kawasaki, MD, } \\
\text { PhD }\end{array}$ & $\begin{array}{l}\text { Sapporo Medical University } \\
\text { School of Medicine, }\end{array}$ & $\begin{array}{l}\text { Designed and } \\
\text { conceptualized study, major } \\
\text { role in the acquisition of data, } \\
\text { revised the manuscript for } \\
\text { intellectual content }\end{array}$ \\
& &
\end{tabular}

\section{References}

1. Ramocki MB, Peters SU, Tavyev YJ, et al. Autism and other neuropsychiatric symptoms are prevalent in individuals with MECP2 duplication syndrome. Ann Neurol. 2009;66:771-782.

2. Temudo T, Oliveira P, Santos M, et al. Stereotypies in Rett syndrome: analysis of 83 patients with and without detected MECP2 mutations. Neurology. 2007;68: 1183-1187.

\section{COVID-19 and Neurologic Disease: Call for Papers!}

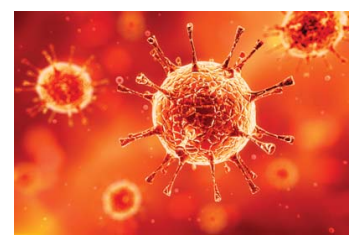

The editors of Neurology are interested in papers that address the neurological aspects of COVID-19 infection and challenges to the management of patients with chronic neurological conditions who have, or are at risk for, the infection. Relevant papers that pass initial internal review will undergo expedited peer review and online publication. We will consider papers posted in preprint servers.

Submit observational studies and clinical trials as Articles and case series and case reports under the Clinical/Scientific Notes category to https://submit.neurology.org/ today!

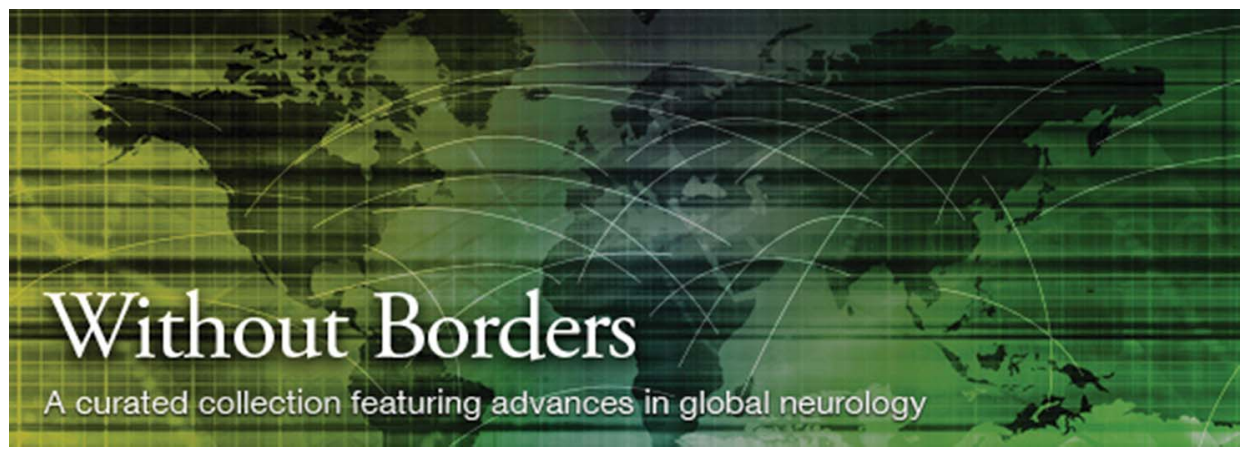

\section{Without Borders - A curated collection featuring advances in global neurology}

This Neurology ${ }^{\circledR}$ special interest website is the go-to source for tracking science and politics of neurology beyond the United States, featuring up-to-the-minute blogs, scholarly perspectives, and academic review of developments and research from Neurology journals and other sources. Curated by Gretchen L. Birbeck, MD, MPH.

\section{Expand your world view at Neurology.org/woborders.}




\section{Neurology}

\section{Stereotyped Upper Limb Movement in MECP2 Duplication Syndrome}

Tomohiro Wakabayashi, Shinobu Fukumura, Satoru Takahashi, et al. Neurology 2021;97;92-94 Published Online before print April 30, 2021

DOI 10.1212/WNL.0000000000012130

This information is current as of April 30, 2021

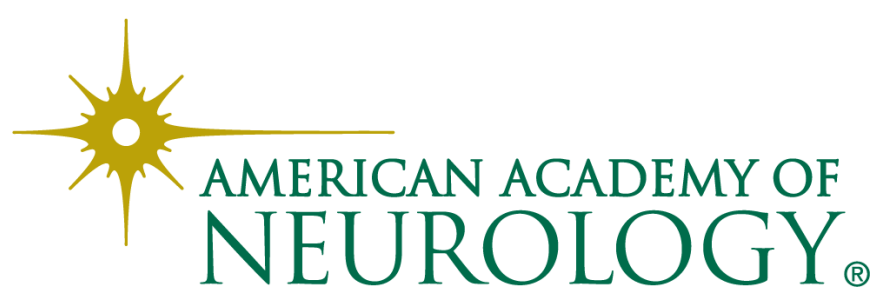




\section{Updated Information \& Services}

References

Citations

Subspecialty Collections

Errata

Permissions \& Licensing

\section{Reprints}

including high resolution figures, can be found at:

http://n.neurology.org/content/97/2/92.full

This article cites 2 articles, 1 of which you can access for free at: http://n.neurology.org/content/97/2/92.full\#ref-list-1

This article has been cited by 1 HighWire-hosted articles: http://n.neurology.org/content/97/2/92.full\#\#otherarticles

This article, along with others on similar topics, appears in the following collection(s):

\section{All Genetics}

http://n.neurology.org/cgi/collection/all_genetics

All Movement Disorders

http://n.neurology.org/cgi/collection/all_movement_disorders

\section{Chorea}

http://n.neurology.org/cgi/collection/chorea

Nonepileptic seizures

http://n.neurology.org/cgi/collection/nonepileptic_seizures

Rett Syndrome

http://n.neurology.org/cgi/collection/rett_syndrome

An erratum has been published regarding this article. Please see next page or:

/content/98/9/384.1.full.pdf

Information about reproducing this article in parts (figures,tables) or in its entirety can be found online at:

http://www.neurology.org/about/about_the_journal\#permissions

Information about ordering reprints can be found online:

http://n.neurology.org/subscribers/advertise

Neurology ${ }^{\circledR}$ is the official journal of the American Academy of Neurology. Published continuously since 1951, it is now a weekly with 48 issues per year. Copyright @ 2021 American Academy of Neurology. All rights reserved. Print ISSN: 0028-3878. Online ISSN: 1526-632X.

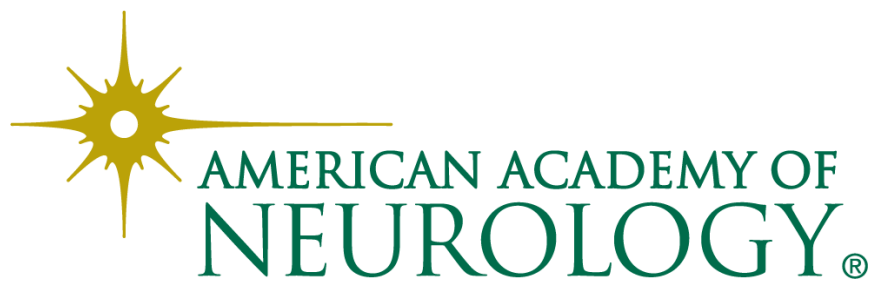




\section{Stereotyped Upper Limb Movement in MECP2 Duplication Syndrome}

Neurology ${ }^{\circledR}$ 2022;98:384. doi:10.1212/WNL.0000000000012757

In the Video NeuroImage article "Stereotyped Upper Limb Movement in MECP2 Duplication Syndrome" by Wakabayashi et al., ${ }^{1}$ the first sentence should read: "A 23-year-old man had epilepsy, intellectual disability, and a stereotyped movement (Figure 1 and Video 1), which was exacerbated by emotion." The authors regret the error.

\section{Reference}

1. Wakabayashi T, Fukumura S, Takahashi S, et al. Stereotyped upper limb movement in MECP2 duplication syndrome. Neurology. 2021; 97(2):92-94

\section{Targeted Next-Generation Sequencing Panels in the Diagnosis of Charcot-Marie-Tooth Disease}

Neurolog ${ }^{\circledR}$ 2022;98:384. doi:10.1212/WNL.0000000000010635

In the article "Targeted Next-Generation Sequencing Panels in the Diagnosis of CharcotMarie-Tooth Disease" by Cortese et al., ${ }^{1}$ the gene named throughout the article should be FGD4. In the amended supplementary table e-2 (doi.org/10.5061/dryad.kp8pb51), the mutation in patient 111 should be PMP22: c.68G $>\mathrm{C}$ p.(Thr23Arg), and the mutation in patient 21 should be GARS: c.880G>C p.Gly294Arg. The authors regret the errors.

\section{Reference}

1. Cortese A, Wilcox JE, Polke JM, et al. Targeted next-generation sequencing panels in the diagnosis of Charcot-Marie-Tooth disease. Neurology. 2020;94(1):e51-e61.

\section{CORRECTION \& REPLACEMENT}

\section{What Is the Role of Stathmin-2 in Axonal Biology and Degeneration?} Neurolog ${ }^{\circledR}$ 2022;98:384. doi:10.1212/WNL.0000000000013018

In the Basic Science in the Clinic article "What Is the Role of Stathmin-2 in Axonal Biology and Degeneration?" by Benarroch, ${ }^{1}$ a reference to a study by Melamed et al. ${ }^{2}$ was inadvertently omitted at the beginning of the article and miscited elsewhere. The updated references and citations have been added in the replacement version of the article.

In addition, statements regarding TDP-43 in the first paragraph under the "Relationship Among STMN2, TDP-43, and Axonal Degeneration" heading have been corrected in the replacement version of the article. The author agrees with a reader who pointed out that the original wording was not substantiated.

The author regrets the omissions and errors. The original version with the changes highlighted is available from a link in the corrected article.

\section{References}

1. Benarroch E. What is the role of stathmin-2 in axonal biology and degeneration? Neurology. 2021;97(7):330-333.

2. Melamed Z, Lopez-Erauskin J, Baughn MW, et al. Premature polyadenylation-mediated loss of stathmin-2 is a hallmark of TDP-43dependent neurodegeneration. Nat Neurosci. 2019;22(2):180-190. 